PAWEŁ KUŻDOWICZ KRZYSZTOF WITKOWSKI HELENA VIDOVÁ

\title{
Modelling value stream \\ flows in the enterprise supply chain
}

Paweł Kużdowicz, Ph. D. University of Zielona Góra,

Faculty of Economics and Managemen

Prof. Krzysztof Witkowski University of Zielona Góra,

Faculty of Economics and Management

Prof. Helena Vidová Slovak University of Technology in Bratislava, Faculty of Materials Science and Technology in Trnava

\section{Introduction}

To improve the supply chain in an enterprise, it is necessary to continuously monitor the processes, expenditures, and results achieved from cooperation. Progress in the area of process efficiency and the resulting improvement of the supply chain effectiveness can by evaluated regularly using both internal and external criteria. Internal criteria are used to identify deviations of actual states from planned states. Using external criteria also enables the enterprise to continuously search for, measure, and implement products, services, processes, procedures, and standards, for example modeled on those of the best competitors (Witkowski 2010, p. 119).

Evaluation of the enterprise's logistic chain requires simultaneously giving consideration to the diversified information needs of various stakeholder groups, namely external and internal stakeholders. External stakeholders (e.g. authorities, banks) are typically interested in general reports such as the balance sheet or profit and loss statement. Internal stakeholders are interested in detailed reports, 
e.g. concerning cost centers, profit centers, or cost objects, typically prepared in the "plan vs. attainment" convention. This implies application of an integrated approach in which the logistic chain is evaluated in the context of fulfillment of diversified information needs and therefore mapping of various analytical perspectives.

Such an integrated approach to the logistic chain evaluation requires identification (modelling) of flows of the value streams generated at individual chain links. The objective of this paper is to present a concept of modelling such flows in the context of an integrated ERP-class information system. The paper focuses on the value stream flows in the areas of procurement, production, and sales in an enterprise.

\section{The concept of value stream flows}

The source of value stream flows in an enterprise is logistics, i.e. logistic processes which are subject to proper recording and reporting in the enterprise bookkeeping system, which includes the (financial) accounting subsystem and the controlling subsystem. Accounting is responsible chiefly for preparation of the general financial report at the end of the financial year, while Controlling is responsible for internal detailed reporting also in shorter cycles (monthly and quarterly).

\subsection{The notion of value stream flow}

A value stream flow in the logistic chain includes changes of expenditures (costs) and attainments (results) occurring at the individual links of the chain in connection with execution of the procurement, production, and sales processes applied to the manufactured goods. Such changes may be identified in terms of various categories (e.g. expenditure types, attainment types) and/or analytic objects (e.g. cost centers, profit centers, products, customer groups).

Changes of expenditures are typically accompanied by quantitative (material) movements, such as inventory increase or consumption of production means. For example, when material is released for consumption in production, there is a material movement, i.e. the inventory is decreased and consumption is increased. On the other hand, changes of attainments may be connected with material movements (e.g. inventory change) or not (e.g. issuing an invoice to a customer). 
As the execution of production processes progresses, expenditures and attainments change at successive links of the supply chain. Releasing materials for production results in increasing the value of consumed materials and of the production in progress, at the same time decreasing the value of the material inventory. As production orders are closed, the final-product inventory increases and the value of production in progress decreases. Delivery of final products to the customer results in increasing the value of sold products and decreasing the value of final-product inventory.

\subsection{Integrated approach}

Identification of the value stream flows in the context of information needs of various stakeholder groups in an enterprise requires an integrated approach. Let us consider this using the example of internal stakeholder groups, among which the Logistics, Accounting, and Controlling departments are identified (cf. Hölzlwimmer 2009, p. 29). The requirements from Logistics focus on material movements. Subject to analysis is all information which ensures smooth execution of the production and delivery processes. Such information may come from the product-cost accounting provided by Controlling. On the other hand, Controlling relies on information from Logistics, e.g. for the purpose of product calculation. Such information is related to technological specifications (recipes) or product structures as documented in the production plan. The primary task of Controlling is to timely detect any bottlenecks in the enterprise in order to undertake corrective measures. The Accounting department "consumes" the data from Logistics: logistic transactions are subject to valuation for the purpose of their assignment to the general-ledger (GL) accounts and cost objects.

\section{Value stream flows in an ERP system}

Integrated ERP-class information systems enable the enterprise's logistic processes to be mapped in real time. As material movements are recorded, value streams are generated. Therefore, the source of such flows are the processes recorded in the logistic modules of the system, including in particular the sales module, production module, and procurement \& material management module. Those modules record - respectively - invoices (sales), manufacturing processes (production), and purchase/inventory transactions (procurement \& material management). The value stream flows are triggered upon recording the corresponding logistic processes and they consist in generating accounting 
instructions for the GL accounts (Accounting) and debiting or crediting (as appropriate) the cost objects (Controlling) (Nowakowska-Grunt 2010, p. 113).

\subsection{Primary and secondary flows}

Figure 1 below shows a sample diagram of value stream flows in an ERP system. It is assumed that the core link integrating all areas is the accounting module. In that module, business operations recorded in logistic modules are assigned to accounts. Any flow essentially goes from a logistic module to the accounting module and subsequently to the cost accounting modules, including cost center accounting, cost object accounting, and income object accounting (Kużdowicz, Kużdowicz, Witkowski 2012, p. 156).

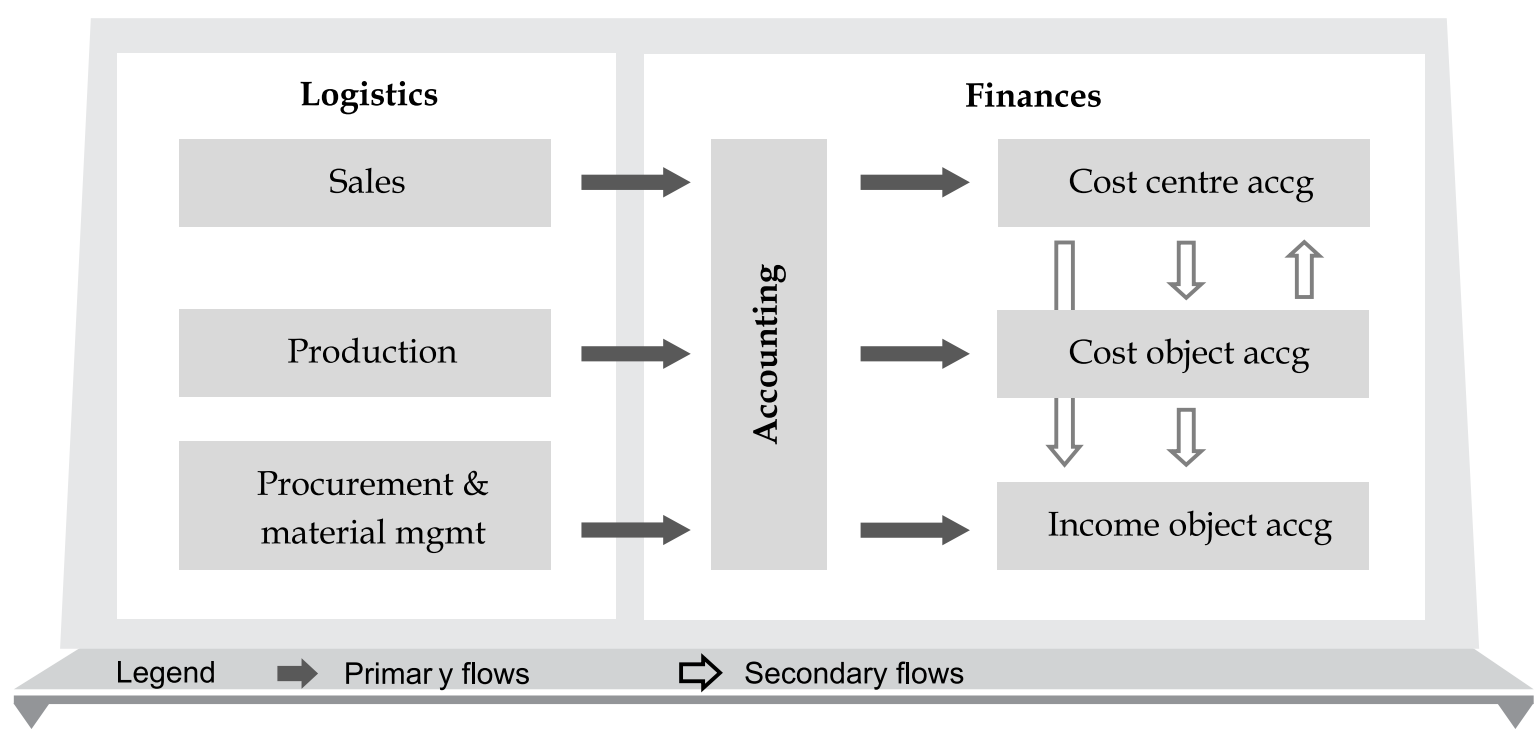

Figure 1. Value stream flows in an ERP system

Source: own work

In terms of relationship with source documents, flows are classified as primary or secondary. Primary flows reflect the flow of source documents (e.g. assigning a sale invoice to a GL account and income object). Secondary flows reflect settlements between cost objects, as well as period closing operations. Settlements between cost objects include cross-posting both between objects of the same category (e.g. between cost centers to reflect settlement of mutual performances) and between different categories (e.g. between cost centers 
and cost objects, to reflect completion of production operations or performance of internal repair orders). Period closing involves, in particular, data reconciliation between the Accounting and Controlling areas (Kużdowicz, Relich, Kużdowicz 2012, p. 265).

\subsection{Basic data}

The integration between the Logistics and Finances areas in the ERP system is ensured by parameters included in so-called basic data determining the directions of value stream flows. Such directions are specified through sets (collections) of GL accounts and costs types assigned to logistic objects in the system (such as stock items, warehouses). The basic data is used by both Logistics and Finances.

The instruments which map the value stream flows in the ERP system are GL accounts and cost types (cf. Hoitsch, Lingnau 2007). GL accounts are essentially used to record business operations for the purpose of financial reporting. Therefore, GL accounts record those business operations which are relevant in particular to the balance sheet, profit and loss statement, and cash flow report. Such accounts correspond to individual items of those reporting

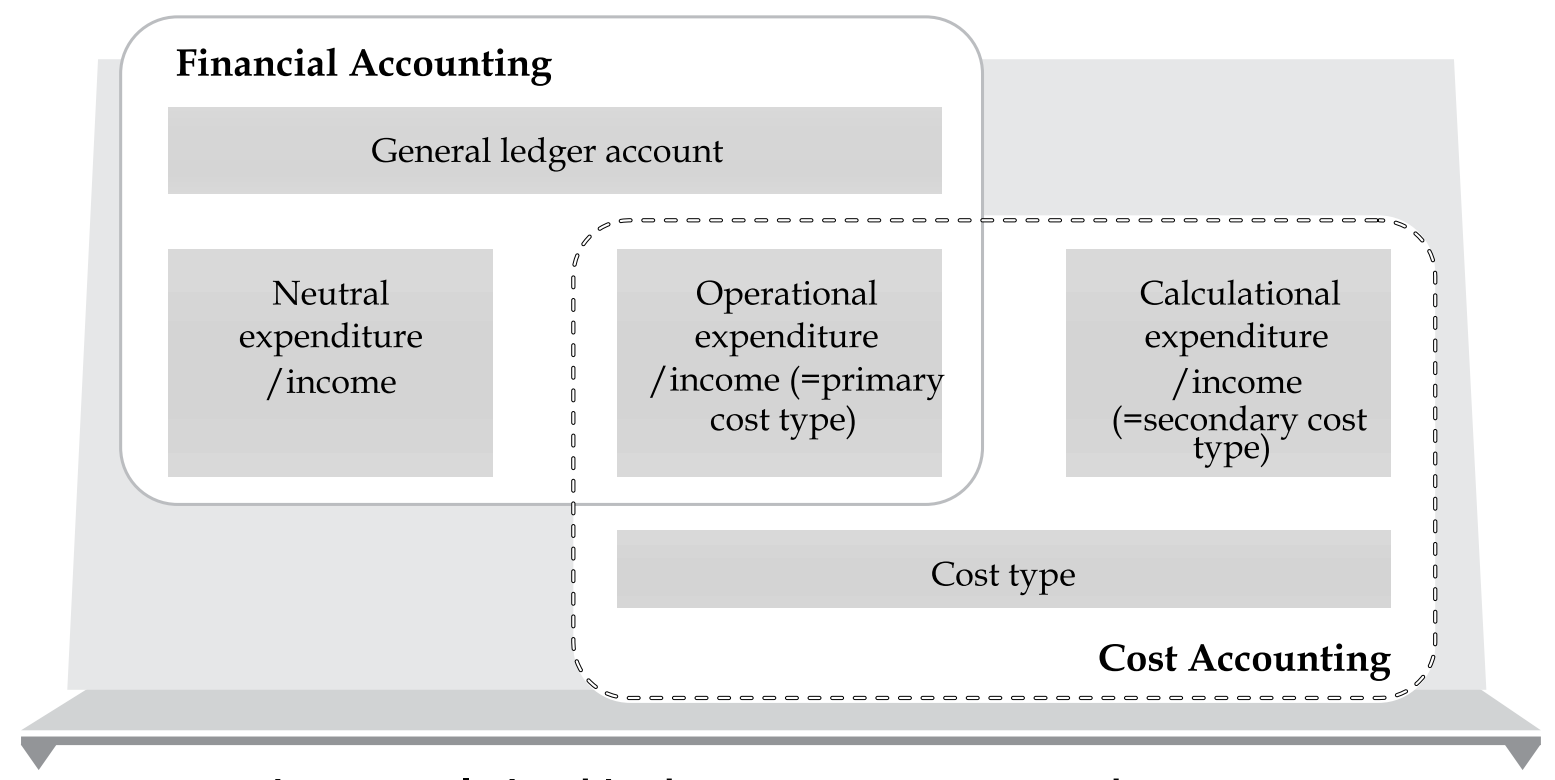

Figure 2. Relationships between GL accounts and cost types

Source: Hölzlwimmer 2009, p. 62 
documents. Cost types are equivalent to accounts in the Cost Accounting area and are used to record flows in which costs centers and cost objects are involved (e.g. consumption of materials for a production order, revenues from sales to a customer or to a region). Cost types are assigned inter alia to calculation schemes and cost-center/object settlement sheets.

Result accounts in GL are classified as accounts with a cost type and accounts without a cost type. Furthermore, there are cost types which are not reflected by any GL accounts (cf. fig. 2). GL accounts with (primary) cost types are used to record primary flows, i.e. flows whose sources are outside the Cost Accounting area. An example are general costs which are posted simultaneously to a result account and to a cost type charged to one or more cost centers. GL accounts without cost types are used to record so-called neutral costs and incomes, i.e. those which are not related to the core business. For example, such accounts enable the result of financial or extraordinary operations to be calculated. The secondary cost types (e.g. those related to calculation costs or to allocation of secondary costs to auxiliary cost centers) are defined only in the Cost Accounting area and are not related to any GL accounts.

\section{Examples of flow models}

To identify value stream flows in a logistic chain, mapping models are applied which enable the analyzed flows to be illustrated graphically. Among the most frequently used are Porter's value chain models and the SCOR (Supply Chain Operations Reference) model developed for analyzing supply chains and identify potential improvements in flows of goods, labor, and information (cf. Trocki 2003, p. 160; Witkowski 2003, p. 22; Zając, Zając 2004, p. 27). The remaining part of this paper focuses on examples of application of the SCOR model for identification of value stream flows in procurement, production, and sales processes. Flows in individual processes are analyzed both from the point of view of Logistics (material movements) and from the point of view of Accounting and Controlling (value stream flows). Processes are always mapped through relevant documents (receipts etc.).

\subsection{Value stream flows in procurement processes}

Fig. 3 shows the possible documents generated in procurement process recording. The following logistic processes in the Procurement area are distinguished: purchase order, stock receipt, bill input, and payment output. The 
documents are accompanied by respective streams of primary value flows in the financial areas (Accounting and Controlling).

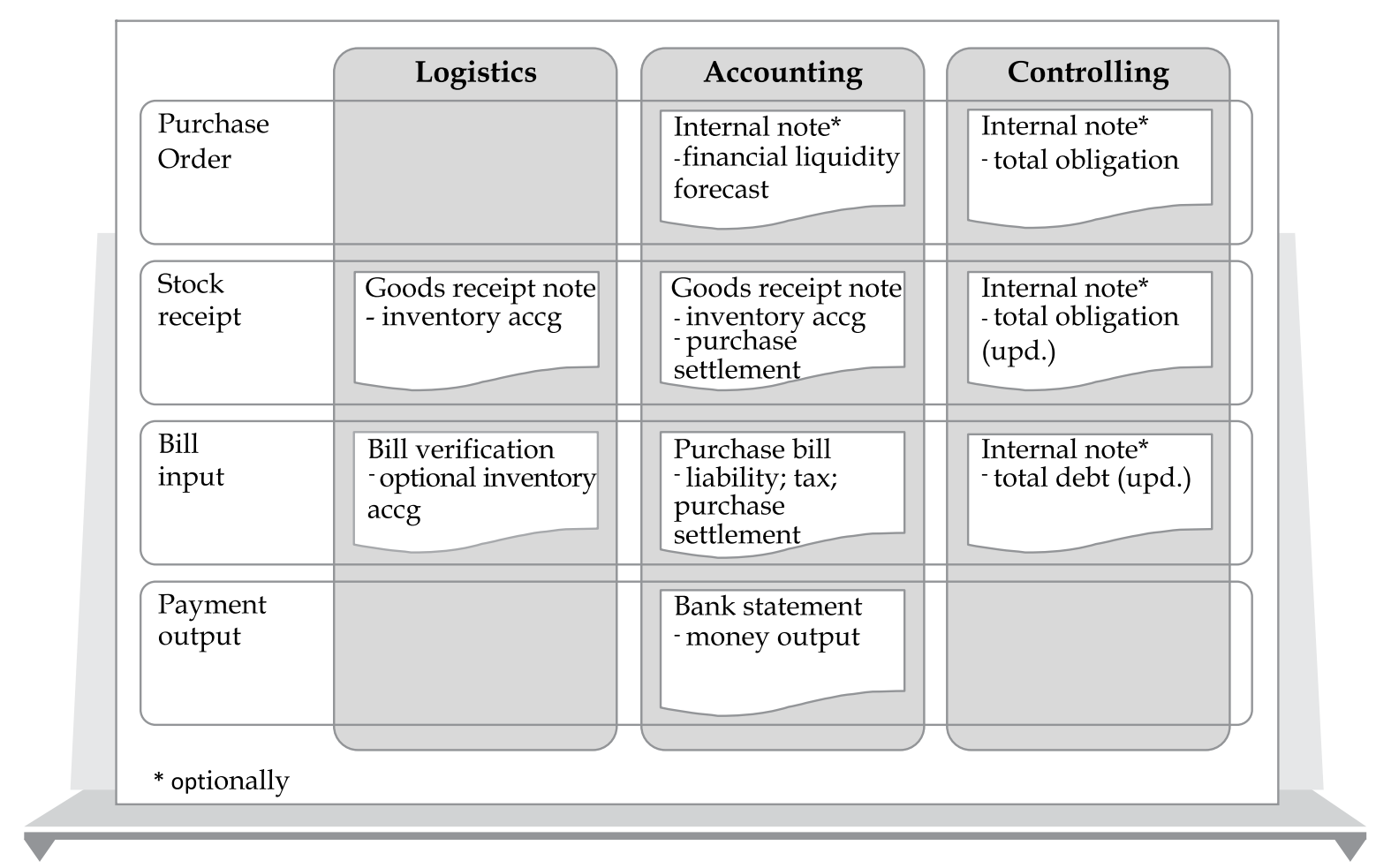

Figure 3. Value stream flows in procurement processes

Source: own work, based on Hölzlwimmer 2009, p. 93

The flows of the contemplated streams in the Accounting area are obligatory. They include posting the following to GL accounts: stock receipts, purchase bills, payments of the obligation. Flows in the Controlling area are optional and include in particular recording the total obligation in connection with placing orders for materials, as well as its updating in course of subsequent (follow-up) processes. Individual processes are triggered automatically by recording the source documents in the Logistics area: internal obligation note (at issuing the order), goods receipt note (at receipt of the goods), purchase bill (at approval of the controlled bill). Individual streams are posted to GL accounts and cost objects (as appropriate) through default account assignment defined at the moment of recording the order or any changes to subsequent (follow-up) documents. An 
exception is the bank statement document whose source is outside Logistics and which is recorded only in Accounting.

\subsection{Value stream flows in production processes}

Fig. 4 shows the possible documents generated in production process recording. The following logistic processes in the Production area are distinguished: production order, requisitions (material)data entry, production data entry, and completion notices.

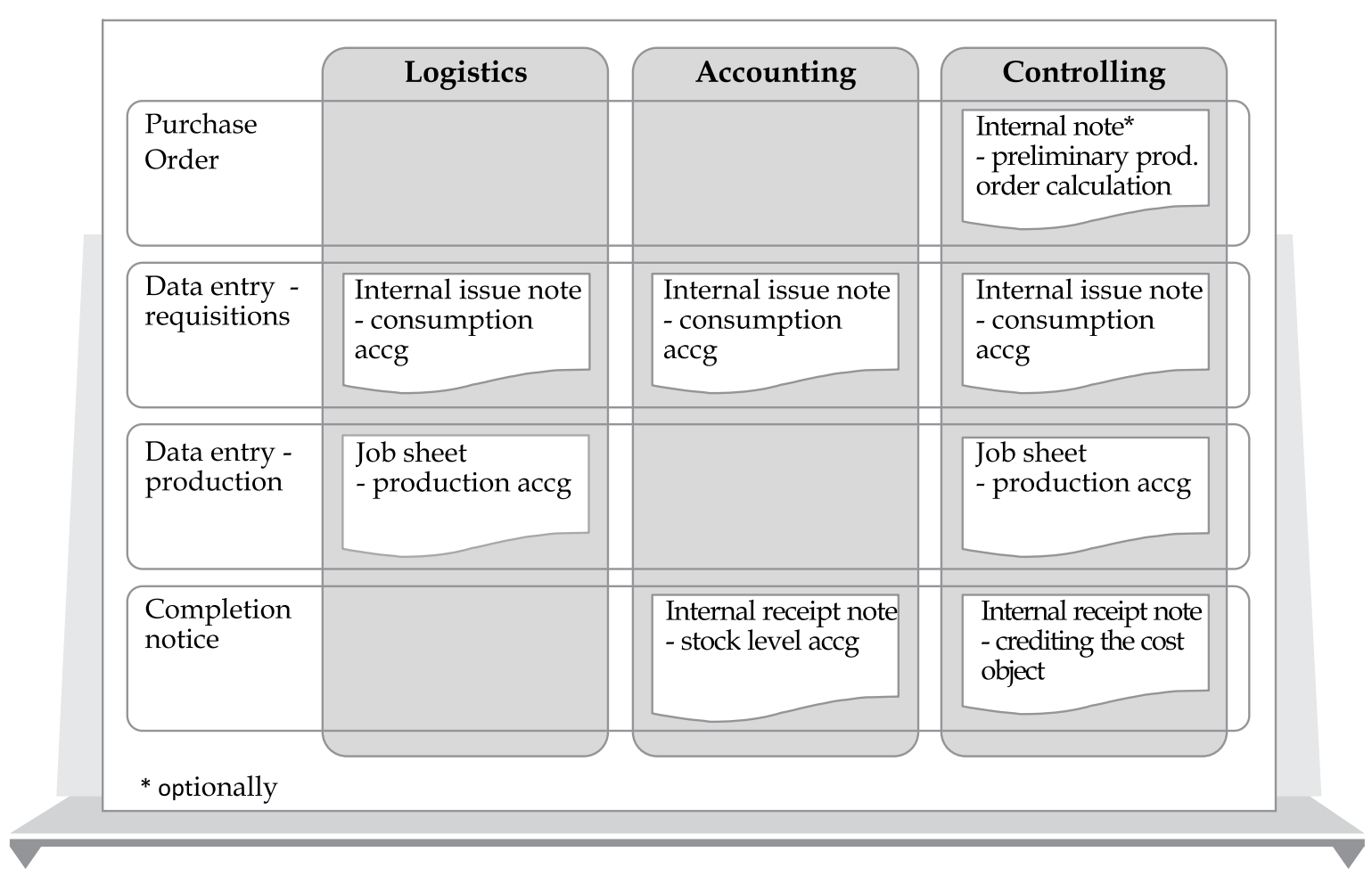

Figure 4. Value stream flows in production processes

Source: own work

It is assumed that the production process is triggered by the production order document. It does not generate any flows in the Accounting area, but optionally enables performing preliminary production order calculation in the Controlling area. The first document generating value stream flows on GL accounts is the data entry requisitions note. In terms of value, it is credited to the inventory account and debited to the material consumption account, at the current inventory price 
of the given product. At the same time, the cost object assigned to the production order is posted. Data entry production reports are based on so-called job sheets and reflect completed working operations. The accounting is performed through cost objects, using the direct-labor and machine-hour cost types. Therefore, production reports generate value stream flow only in the Controlling area, bypassing the Accounting area. The document which terminates the process contemplated here is the completion report which generates value stream flows in both Accounting and Controlling. Receipt of the final product to the warehouse (at a predefined value, e.g. current cost, standard cost, postulated cost) is posted to the GL accounts. Additionally, the cost object is debited (at the same value).

\subsection{Value stream flows in sales processes}

Fig. 5 shows the possible documents generated in sales process recording. The following logistic processes in the Sales area are distinguished: customer order, external shipping, sales invoice, and payment input.

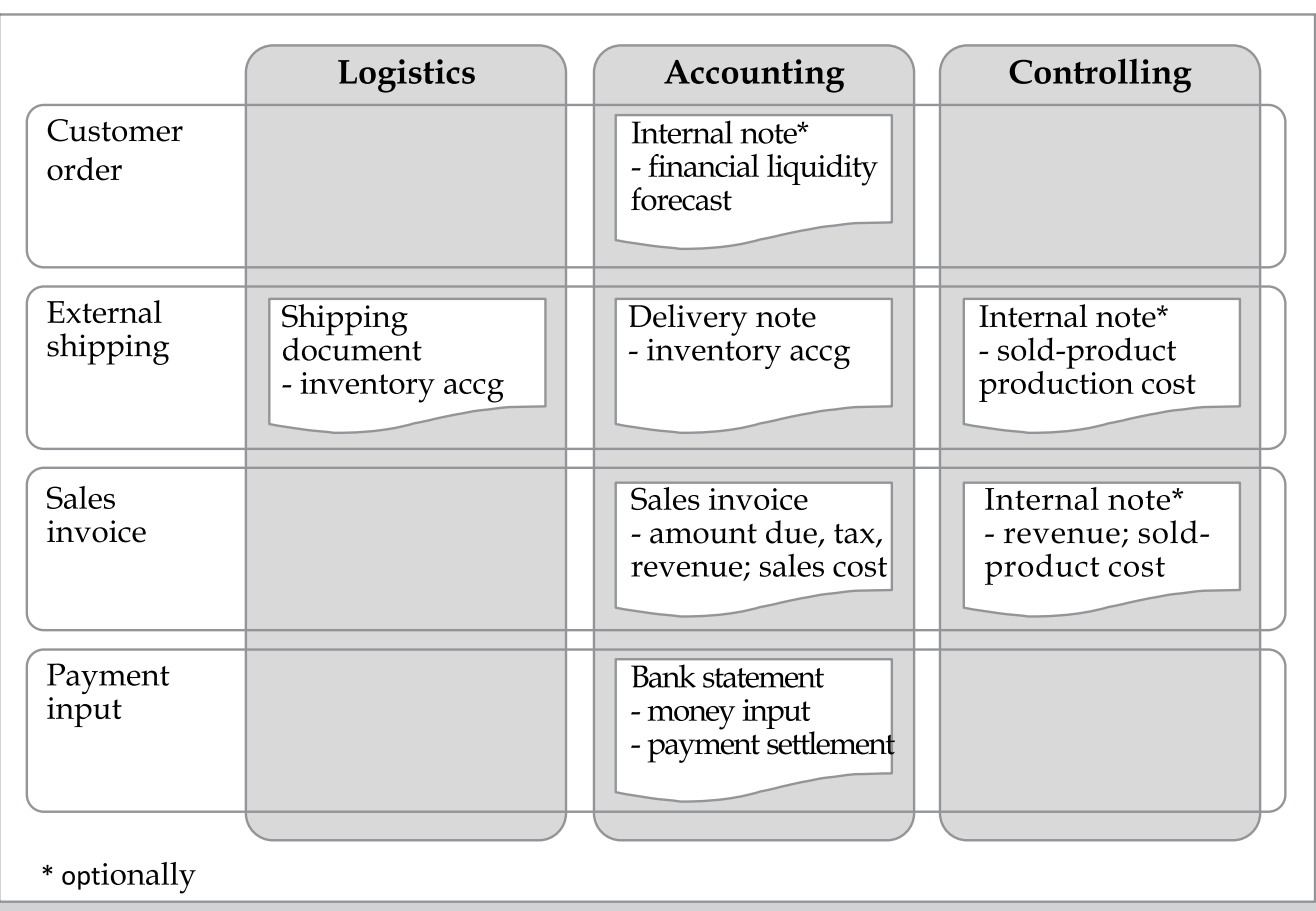

Figure 5. Value flows in sales processes

Source: own-developed, based on Hölzlwimmer 2009, p. 172 
It is assumed that the sales process is triggered by the customer's order document. In practice, it may be preceded by a request for proposal and a proposal, which documents do not affect the contemplated flows after all. While the customer order does not generate entries in GL accounts, it is visible in the financial liquidity forecast. The first sales document generating value stream flows on GL accounts is the shipping document. The inventory account is credited and the sales settlement account is debited at the current inventory price of the given product. Optionally, the relevant cost object may be also debited. The subsequent (follow-up) document is an invoice which triggers postings to GL accounts (amount due, tax, revenue, product sales cost) and to cost objects (e.g. revenue, production costs of sold products by customer, region, or segment etc.). Also, the invoice closes the shipping document by generating additional entries on the sales settlement accounts in the GL. The final document in the contemplated process is the bank statement which confirms that the payment has been effected and settled. In case of discount, additional accounting entries in Controlling are optionally generated, decreasing the postulated revenues.

\subsection{Period closing}

At period closing, the (primary) value stream flows in logistic processes in the Procurement, Production, and Sales areas are aggregated in order to reconcile them between Accounting and Controlling. Before reporting the data, further processing (through secondary flows), cross-posting, and revaluation are performed as necessary. The Accounting area is responsible for data preparation for the balance sheet and the profit and loss statement. The Controlling area provides various stakeholder groups with information e.g. from cost-center accounting and profit-center accounting. The data processing for the purpose of period closing is typically performed sequentially, i.e. the accounting data processing precedes the controlling data processing. In special cases, controlling data may be used to manually post additional accounting entries. The period closing involves also data reconciliation between Accounting and Controlling, necessary mainly because those two subsystems use different cost accounting systems (cf. Kużdowicz, Kużdowicz 2012, p. 261; Kużdowicz, Kużdowicz, Witkowski 2012, p. 157). 


\section{Conclusions}

Managing the supply chain in an enterprise is closely related to modelling the value stream flows occurring at individual links of the chain. Mapping the business processes in real time, using modern IT systems, especially ERP systems, ensures more effective management. In particular, it enables the data to be analyzed from various perspectives. The usability of such data depends on how the flows are modeled for the purpose of their subsequent analysis. Such usability may however fluctuate (decrease) due to the enterprise growth and market changes. Therefore, the adopted solution should be continuously kept up to date.

One direction of further research is the development of a method of modelling the value stream flows in the context of their continuous adaptability to the changes in the environment and to the enterprise growth. In other words, the solution should follow the constantly changing and improving supply chain of the enterprise.

\section{Summary}

\section{Value stream flows in the supply chain}

This paper discusses supply chain management in an enterprise. A concept of modelling value stream flows defined in an integrated ERP-class information system is presented. The paper focuses on value stream flows in the areas of procurement, production, and sales in an enterprise. Such flows are illustrated by examples.

Keywords: $\quad$ supply chain, SCOR model, stream flow, ERP system.

\section{Streszczenie}

\section{Modelowanie przepływów strumieni wartości w łańcuchu dostaw przedsiębiorstwa}

Artykuł podejmuje problematykę zarzadzania łańcuchem dostaw w przedsiębiorstwie. Przedstawiono koncepcję modelowania przepływów strumieni wartości osadzonych w zintegrowanym systemie informatycznym klasy ERP. Skoncentrowano się na przepływach strumieni wartości w obszarach zaopatrzenia, produkcji oraz sprzedaży przedsiębiorstwa ilustrując je na przykładach. 


\section{Słowa}

kluczowe: $\quad$ tańcuch dostaw, model SCOR, strumień wartości, system ERP.

\section{References}

1. Bakalarczyk S., Gradzki R., (2012), Risk of economic activity of metallurgical industry enterprises, 21st International Conference on Metallurgy and Materials, Brno, CD-ROM.

2. Banasova L., Caganova D., Cambal M., Sujanova J., (2011), The Identification Procedure for Key Managerial Competencies in Industrial Enterprises, Annals of DAAAMS for 2011 \& Proceedings of the 22nd International DAAAM Symposium, Volume 22, No. 1, Vienna, Austria.

3. Bednár R., Vidová H., Beluský M., (2012), Lean Principles Application in Business Logistics, 21st International Conference on Metallurgy and Materials, Brno 2012, CD-ROM.

4. Hoitsch, H. J., Lingnau (2007), V., Kosten- und Erlösrechnung. Eine controllingorientierte Einführung, 6. Aufl. Springer Verlag, Berlin.

5. Hölzlwimmer A., (2009), Integrierte Werteflüsse mit SAP ERP, Galileo Press, Bonn.

6. Jakabova M., Hrablik Chovanova H., Urdzikova J., (2010), Project Management as an Instrument in Environmentally Oriented Business, in: Towards Green Economy: Young Researchers Perspective, Litomysl Seminar Publishing, Prague.

7. Kużdowicz D., Kużdowicz P., Witkowski K., (2012), The application of normal and actual cost accounting in production companies, CO-MAT-TECH: Global Crisis - Opportunities and Threats, 20th International Scientific Conference, AlumniPress, Trnava, Slovak Republic, s. 154-159.

8. Kużdowicz D., Kużdowicz P., (2012), Closure of reporting period in companies using standard software, Znalosti pro tržní praxi - význam znalostí v aktuálni fázi ekonomického cyklu : sborník z mezinárodni vědecké conference, Societas Scientiarum Olomucensis II, Olomouc, Czechy, s. 258-263.

9. Kużdowicz P., Relich M., Kużdowicz D., (2012), Cross-company data flows with ERP system, Znalosti pro tržní praxi - význam znalostí v aktuálni fázi ekonomického cyklu : sborník z mezinárodni vědecké konference. Societas Scientiarum Olomucensis II, Olomouc, Czechy, s. 264-269.

10. Lenort, R. Staš, D. Samolejová, A., (2012), Capacity Planning in Operations Producing Heavy Plate Cut Shapes. In: Metalurgija, July-September 2009, vol. 48, no. 3, pp. 209-211.

11. Nowakowska-Grunt J.(2010), Operatorzy logistyczni, a efekt byczego bicza w tańcuchu dostaw, "Logistyka” nr 4.

12. Schmidt, A. (2008), Kostenrechnung. Grundlagen der Vollkosten-, Deckungsbeitrags- und Plankostenrechnung sowie des Kostenmanagements, W. Kohlhammer Druckerei GmbH + Co. KG, Stuttgart. 
13. Škapa R., Klapalová A., (2009), Reverse Logistics in the Czech Republic: Outcomes of the Preliminary Research, In ICABR. Vyd. 1. Brno: MZLU v Brně, 2009, s. 1254-1265.

14. Trocki M., (2003), Zarządzanie projektami, PWE, Warszawa.

15. Witkowski J., (2003), Zarządzanie łańcuchem dostaw, PWE, Warszawa.

16. Witkowski J., (2010), Zarządzanie łańcuchem dostaw. Wyd II, PWE, Warszawa.

17. Witkowski K., (2010), The aspect of integrated logistics for sustainable development, Procedings of the Joint International IGIP-SEFI Annual Conference: Diversity unifies - Diversity in Engineering Education, Trnava - Slovakia.

18. Zając M., Zając P., (2004), Zarzadzanie łańcuchem dostaw z wykorzystaniem modelu SCOR, „Logsityka” 3/2004, ILIM, Poznań. 